
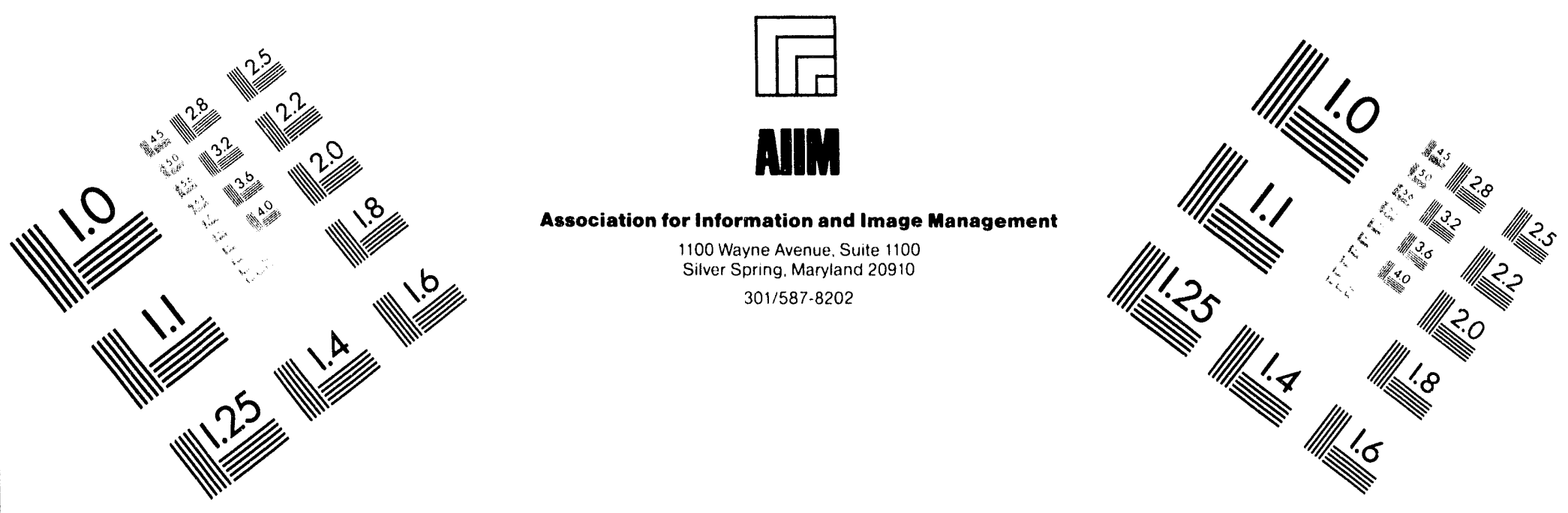

\title{
Centimeter
}

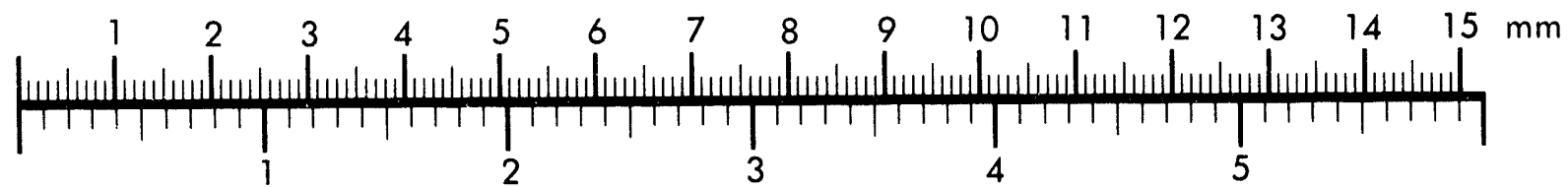

Inches
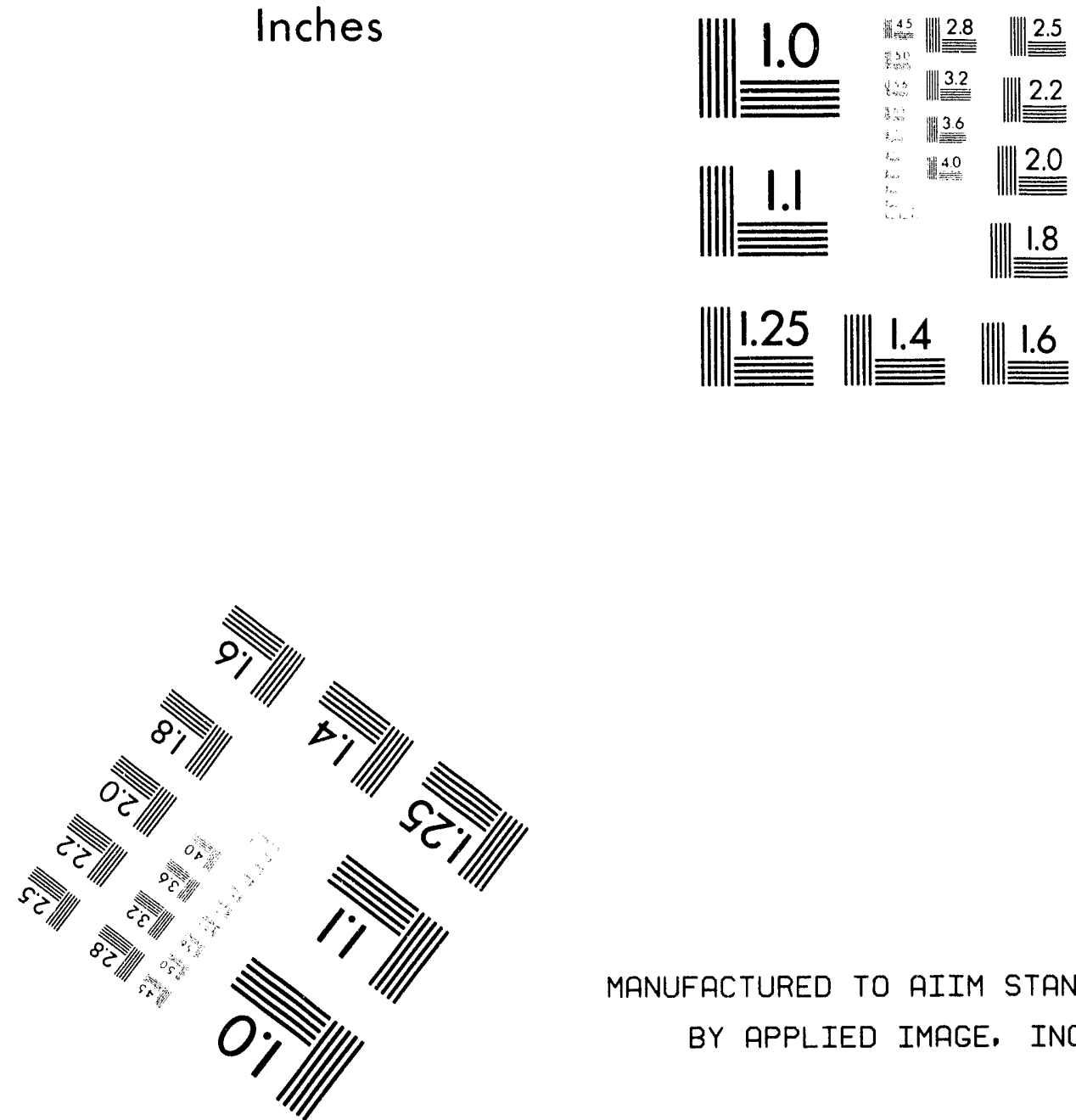

MANUFACTURED TO AIIM STANDARDS

BY APPLIED IMAGE, INC.

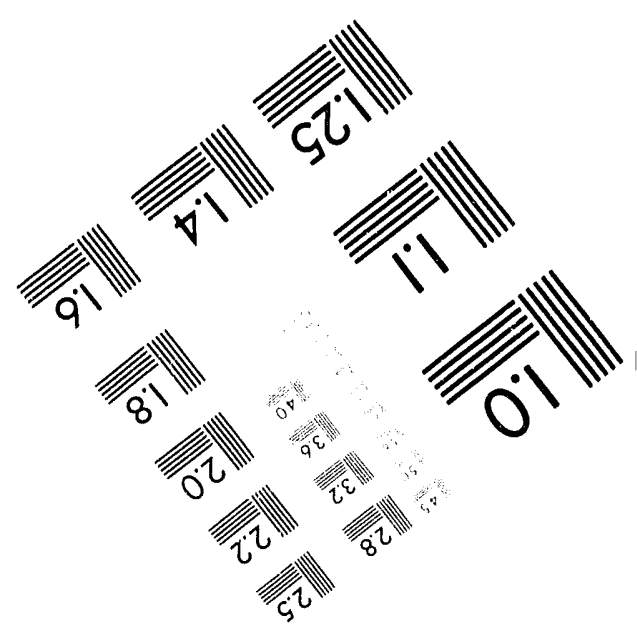



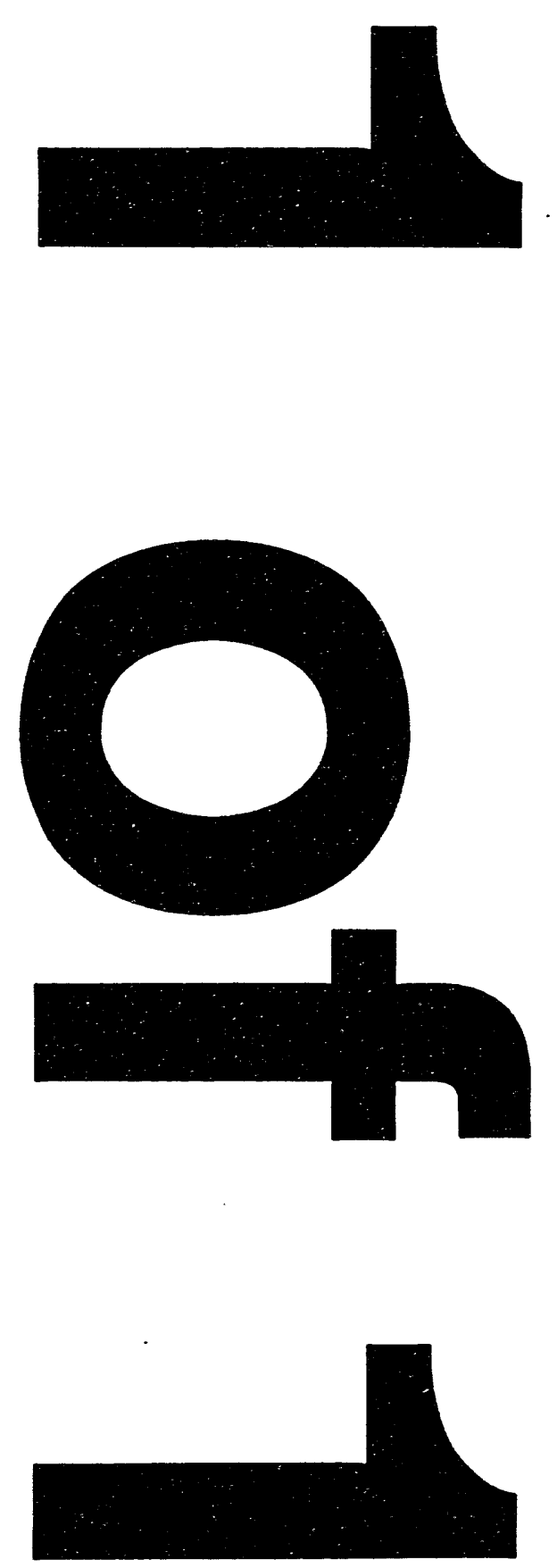
December 1, 1993 through February 28, 1994

Project Title:

DOE Grant Number: ICCI Project Number:

Principal Investigator:

Co-Principal Investigator:

Other Investigators:

Project Manager:

\section{DEVELOPMENT OF NOVEL COPPER-BASED SORBENTS FOR HOT-GAS CLEANUP}

\author{
DE-FC22-92PC92521 (Second Year) \\ R92-1/6.1B-3M \\ Javad Abbasian, Institute of Gas \\ Technology \\ Maria Flytzani-Stephanopoulos, \\ Massachusetts Institute of \\ Technology \\ Andy H. Hill, Institute of Gas \\ Technology, Zhijiang Li, \\ Massachusetts Institute of \\ Technology \\ Franklin I. Honea, Illinois \\ Clean Coal Institute
}

\section{ABSTRACT}

The objective of this investigation is to evaluate two novel copper-based sorbents, namely copper-chromium and copper-cerium, for their effectiveness in removing hydrogen sulfide from fuel gas in the temperature range of $650^{\circ}$ to $850^{\circ} \mathrm{C}$. Such high temperatures will be required for the new generation of gas turbines (inlet $>750^{\circ} \mathrm{C}$ ) in Integrated Gasification Combined Cycle (IGCC) systems.

The effect of pre-reduction with $\mathrm{H}_{2}$ in the presence of $\mathrm{H}_{2} \mathrm{O}$ on the performance of the sorbents in cyclic sulfidation/ regeneration, was studied in a thermogravimetric analyzer (TGA) and in a fixed-bed reactor at $750^{\circ} \mathrm{C}$.

The results of the TGA tests indicate that pre-reduction of the sorbents is very fast in either $10 \%$ or $30 \% \mathrm{H}_{2}$, and that reduction is faster while sulfidation is slower in $30 \% \mathrm{H}_{2}$. Without sorbent pre-reduction, sulfidation consists of two stages, a reduction-dominating and a sulfidation-dominating stage. Sulfidation apparently takes place before reduction is complete. During regeneration some copper/cerium sulfates may have formed and $\mathrm{Cu}_{2} \mathrm{O}$ may have formed in addition to $\mathrm{CuO}$.

The fixed-bed reactor tests show that at $750^{\circ} \mathrm{C}$ : (1) prereducing the CuO- $\mathrm{Cr}_{2} \mathrm{O}_{3}$ with $\mathrm{H}_{2}$ does not effect the reactivity of the sorbent towards $\mathrm{H}_{2} \mathrm{~S}$ at either the high or low $\mathrm{H}_{2}$ feed gas concentrations and (2) when $30 \% \mathrm{H}_{2}$ was used during sulfidation of either sorbent, the first $\mathrm{H}_{2} \mathrm{~S}$ breakthrough occurs earlier than when $10 \% \mathrm{H}_{2}$ was used.

"U.S. DOE Patent Clearance is not NOT required prior to the publication of this document"

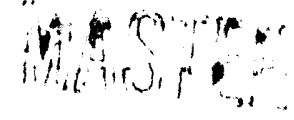




\section{EXECUTIVE SUMMARY}

Development of technology for coal gas desulfurization to sufficiently low levels at temperatures of $600^{\circ}$ to $850^{\circ} \mathrm{C}$ is now recognized as crucial to efficient and economic coal utilization in emerging technologies such as coal gasification-combined cycle power generation (using gas turbines) and gasifier/fuel cell power plants. The implementation of hot gas desulfurization technology relies heavily on the development of regenerable metal oxide sorbent materials which have high sulfur capacity and can efficiently remove $\mathrm{H}_{2} \mathrm{~S}$ (from several thousand ppm levels down to a few ppm) over many cycles of sulfidation/regeneration.

In recent years it has been shown that certain mixed oxides have superior properties compared to single oxides for hot gas cleanup. Compounds of zinc and iron oxides, zinc ferrites, such as $\mathrm{ZnFe}_{2} \mathrm{O}_{4}$, and zinc and titanium oxides, such as $\mathrm{ZnTiO}_{3}$, have reached pilot-stage desulfurization testing. However, at sulfidation temperatures above $600^{\circ}$ to $700^{\circ} \mathrm{C}$, zinc ferrites and titanates will suffer zinc losses. Such high temperatures will be required for the new generation gas turbines (with inlet temperatures exceeding $750^{\circ} \mathrm{C}$ ). If gas cleanup can be performed at matching conditions, then higher power plant cycle efficiency gains will be realized.

Copper oxide-based sorbents have been examined to a lesser extent than zinc oxide sorbents for high-temperature gas desulfurization. In a recently completed ICCI-funded program, the IGT/MIT team systematically examined and ranked several novel binary oxides of copper in terms of their sulfidation equilibria, reduction stability, sulfidation reactivity, and regenerability at temperatures in the range of $650^{\circ}$ to $850^{\circ} \mathrm{C}$. The results of this study indicate that mixed binary oxides of copper with chromium $\left(\mathrm{CuO}-\mathrm{Cr}_{2} \mathrm{O}_{3}\right)$ and cerium $\left(\mathrm{CuO}-\mathrm{CeO}_{2}\right)$ are the most promising sorbents for such high temperature fuel gas cleanup applications. In various sulfidation/regeneration tests, both sorbents were capable of removing $\mathrm{H}_{2} \mathrm{~S}$ from a hot fuel gas to very low levels (<10 ppm) at temperatures as high as $850^{\circ} \mathrm{C}$ with good sorbent regenerability in cycling process. However, additional work was needed to achieve overall sorbent optimization.

The objective of this research program is to evaluate two novel copper-based sorbents (that is, copper-chromium and copper-cerium) for their effectiveness in removing hydrogen sulfide from fuel gas in the temperature range of $650^{\circ}$ to $850^{\circ} \mathrm{C}$.

In this two year program, binary oxides of copper with oxides of chromium and cerium are prepared at various sorbent compositions. The structural effects of chromium oxide and cerium oxide (additives) to copper oxide in sorbent synthesis 
and reductive sulfidation are determined. The results of this program will be used to identify the most promising copperbased sorbent for high temperature application that can be further developed as an alternative to the zinc-based sorbents.

In the parametric sulfidation tests conducted in the first year of the present program the $\mathrm{CuCr}_{2} \mathrm{O}_{4}$ sorbent reduced the $\mathrm{H}_{2} \mathrm{~S}$ concentration of the feed gas from 5000 ppmv to less than 1 to $10 \mathrm{ppmv}$ at $850^{\circ} \mathrm{C}$ at copper conversion levels from $30 \%$ to $50 \%$. In the sulfidation tests conducted at $750^{\circ} \mathrm{C}, \mathrm{H}_{2} \mathrm{~S}$ was not observed until $60 \%-90 \%$ of the copper was utilized. Increasing the $\mathrm{H}_{2}$ concentration in the feed gas significantly reduced the first $\mathrm{H}_{2} \mathrm{~S}$ breakthrough time.

The CuO- $\mathrm{CeO}_{2}$ sorbent was also capable of removing $\mathrm{H}_{2} \mathrm{~S}$ to very low levels comparable to the $\mathrm{CuO}-\mathrm{Cr}_{2} \mathrm{O}_{3}$ sorbent. The $\mathrm{CuO}-$ $\mathrm{CeO}_{2}$ sorbent appeared to be less effective after the first cycle at all conditions tested, which may be attributable to sulfate formation during the regeneration of the $\mathrm{CuO}-\mathrm{CeO}_{2}$. As Owith the $\mathrm{CuO}-\mathrm{Cr}_{2} \mathrm{O}_{3}$ sorbent, increasing the $\mathrm{H}_{2}$ concentration in the feed gas reduced the first $\mathrm{H}_{2} \mathrm{~S}$ breakthrough time significantly. Both sorbents were found to reduce rapidly consuming $\mathrm{H}_{2}$. $\quad\left(\mathrm{H}_{2}\right.$ is later released through the reaction of the metallic copper with the $\mathrm{H}_{2} \mathrm{~S}$, however). Small amounts of $\mathrm{SO}_{2}$ were also observed during the initial stages of sulfidation with both sorbents.

Work to be conducted in the second year of this program will continue with the development of the sorbents as well as address the issues raised above. In this regard, sulfidation /regeneration tests will be conducted to determine the effects of pre-reduction of the sorbents with $\mathrm{H}_{2}, \mathrm{H}_{2}$ concentration, and regeneration conditions on the sorbents performance.

During this quarter, sorbent testing in the thermogravimetric analyzer (TGA) continued. The effects of: (1) $\mathrm{H}_{2}$ concentration in the feed gas on the rate of sorbent reduction and sulfidation and, (2) pre-reduction on the rate of sulfidation of the $\mathrm{CuO}-\mathrm{Cr}_{2} \mathrm{O}_{3}$ and $\mathrm{CuO}-\mathrm{CeO}_{2}$ sorbents were determined. Tests were conducted with four additional copperrich or additive-rich sorbents to determine the effect of sorbents composition on the sorbent pre-reduction rate in $\mathrm{H}_{2} / \mathrm{H}_{2} \mathrm{O}$ and sulfidation rate.

The results of the TGA tests indicate that pre-reduction of the sorbents is very fast in either $10 \%$ or $30 \% \mathrm{H}_{2}$, and that reduction is faster in $30 \%$ than in $10 \% \mathrm{H}_{2}$. The initial sulfidation rate following pre-reduction may be slower under $30 \% \mathrm{H}_{2}$. Sulfidation without pre-reduction consists of two stages, a reduction-dominating stage and a sulfidationdominating stage. Sulfidation apparently takes place before 
reduction is complete. Weight changes during regeneration of the CuO- $\mathrm{CeO}_{2}$ suggest that some copper or cerium sulfates may have formed and for the $\mathrm{CuO}-\mathrm{Cr}_{2} \mathrm{O}_{3}$, that other copper oxides may have formed.

Sulfidation-regeneration cycles for sorbents with molar ratios of $\mathrm{CuO} / \mathrm{CeCeO}_{2}=1: 3,3: 1$ and $\mathrm{CuO} / \mathrm{Cr}_{2} \mathrm{O}_{3}=1: 3,3: 1$ were also carried out in the TGA during this quarter to examine the effect of sorbent composition on the reduction-sulfidationregeneration rates.

The effects of pre-reducing the sorbents and $\mathrm{H}_{2}$ feed gas concentration on the $\mathrm{H}_{2} \mathrm{~S}$ removal efficiency of the CuO-Cr2O3 and $\mathrm{CuO}-\mathrm{CeO} 2$ sorbents were also studied in multicycle sulfidation/regeneration tests using a fixed-bed reactor. These tests show that: (I) pre-reducing the $\mathrm{CuO}-\mathrm{Cr}_{2} \mathrm{O}_{4}$ with $\mathrm{H}_{2}$ does not effect the reactivity of the sorbent towards $\mathrm{H}_{2} \mathrm{~S}$ (after three cycles) at either high or low $\mathrm{H}_{2}$ feed gas concentrations and (2) when higher $\mathrm{H}_{2}$ concentration are used during sulfidation of the $\mathrm{CuO}-\mathrm{CeO}_{2}$ sorbent, low levels of $\mathrm{H}_{2} \mathrm{~S}$ appear earlier than when a lower $\mathrm{H}_{2}$ feed gas concentration is used. The origin of the early pre-breakthrough of the $\mathrm{H}_{2} \mathrm{~S}$ will be verified next quarter when pre-reduction-sulfidationregeneration tests are conducted with the $\mathrm{CuO}-\mathrm{CeO}_{2}$ sorbent.

Parametric studies will continue in a fixed-bed and thermogravimetric reactor (TGA) system with the most promising sorbent compositions to select the optimum sorbent composition for "life-cycle" testing. The sulfidation reaction rate will also be determined at elevated pressure (20 atmospheres) in a shallow quartz fluidized-bed reactor to determine the effect of pressure on the performance of the optimized sorbent and to confirm the reaction rate measurements made in the TGA tests. 


\section{OBJECTIVE}

The overall objective of this program is to evaluate two novel copper-based sorbents (that is, copper-chromium and copper-cerium) for their effectiveness in removing hydrogen sulfide from fuel gas in the temperature range of $650^{\circ}$ to $850^{\circ} \mathrm{C}$. The specific objective of this two-year program is to optimize sorbent composition to determine the structural effects of $\mathrm{CeO}_{2}$ and $\mathrm{Cr}_{2} \mathrm{O}_{3}$ addition to copper oxide and to determine the performance of these sorbents at various operating conditions.

The program goals are specifically directed toward gas cleanup priority section 6.1B: Removal of Sulfur-Containing Gases From the Hot Gases Produced by Gasification of High Sulfur Illinois Coal.

The specific goals of this project are to:

1. Prepare and characterize large quantities of two binary copper-based sorbents, namely copper-chromium and coppercerium;

2. Determine the structural effects of cerium oxide and chromium oxide addition in copper oxide;

3. Determine the kinetic effects of additives in sulfidation;

4. Carry out a parametric study of sulfidation with both sorbents in a fixed bed to determine the effects of operating variables;

5. Determine the stability and regenerability of the sorbents in successive cyclic operation.

\section{INTRODUCTION AND BACKGROUND}

The main goal of the ICCI sponsored research on sulfur in coal is to increase the utilization of high-sulfur Illinois coals using a method that is both economical and environmentally acceptable. The market share of high-sulfur coal has suffered losses because of the trend toward more stringent government-imposed limitations on sulfur emission. Thus, there is a real need to develop technologies for reducing sulfur emissions while minimizing solid wastes for disposal.

Integrated Gasification Combined-Cycle (IGCC) Power Plants and Fuel Cell Power Generation Technologies are among the leading contenders for coal conversion. Coal gas 
desulfurization to sufficiently low levels at temperatures of $650^{\circ}$ to $800^{\circ} \mathrm{C}$ is now recognized as crucial to efficient and economic coal utilization in IGCC power generation (using gas turbines) and gasifier/fuel cell power plants. The implementation of hot coal gas desulfurization relies heavily on the development of regenerable sorbent materials which have high sulfur capacity and can efficiently remove $\mathrm{H}_{2} \mathrm{~S}$ (from several thousand ppm levels down to a few ppmv) over many cycles of sulfidation/regeneration. Structural stability and good mechanical strength are additional desired features of the sorbents.

Various transition metal oxides have been studied as regenerable high-temperature desulfurization sorbents. ${ }^{1-3}$ In recent years it has been shown that certain mixed oxides, namely, zinc ferrites and zinc titanates have superior properties compared to single oxides for hot gas cleanup. 4.10 $^{-10}$ However, at sulfidation temperatures above $600^{\circ}-700^{\circ} \mathrm{C}$, these materials suffer zinc losses. Such high temperatures will be required for the new generation gas turbines (with inlet temperatures exceeding $750^{\circ} \mathrm{C}$ ). If gas cleanup can be performed at matching conditions, then higher power plant cycle efficiency gains will be realized.

Copper oxide-based sorbents have been examined to a lesser extent than zinc oxide sorbents for high-temperature gas desulfurization. As copper-based sorbents do not suffer from metal volatility problems, they could be used at temperatures up to $850^{\circ} \mathrm{C}$. In a recent ICCI-funded program," IGT and MIT (in a joint effort) systematically examined and ranked several novel binary oxides of copper in terms of their sulfidation equilibria, reduction stability, sulfidation reactivity, and regenerability at temperatures in the range of $650^{\circ}$ to $850^{\circ} \mathrm{C}$. The sorbents studied included oxides of chromium, cerium, aluminum, magnesium, manganese, titanium, iron, and silicon. The results of this study indicate that mixed binary oxides of copper with chromium ( $\mathrm{Cu}-\mathrm{Cr}-\mathrm{O}$ ) and cerium ( $\mathrm{Cu}-\mathrm{Ce}-\mathrm{O}$ ) are the most promising sorbents for such high temperature hot gas cleanup applications. In various sulfidation/regeneration tests, both sorbents were capable of removing $\mathrm{H}_{2} \mathrm{~S}$ from a hot fuel gas to very low levels (<10 ppm) at temperatures as high as $850^{\circ} \mathrm{C}$ with good sorbent regenerability in cycling process. However, additional work is needed to achieve overall sorbent optimization. The structural effects of $\mathrm{CeO}_{2}$ and $\mathrm{Cr}_{2} \mathrm{O}_{3}$ addition in $\mathrm{CuO}$ and the effects of additives and operating conditions on sulfidation kinetics, stability and regenerability of the sorbent should be determined.

The objective of this investigation is to evaluate two novel copper-based sorbents (that is, copper-chromium and 
copper-cerium) for their effectiveness in removing hydrogen sulfide from fuel gas in the temperature range of $600^{\circ}$ to $850^{\circ} \mathrm{C}$.

In this two-year program the structural effects of chromium oxide and cerium oxide (additives) to copper oxide in sorbent synthesis and reductive sulfidation are determined. The effects of additive and operating conditions on the performance of the sorbents are also determined. The results of the proposed program will be used to identify the most effective copper-based sorbent for high temperature application that can be further developed as an alternative to the zinc-based sorbents.

\section{EXPERIMENTAL PROCEDURE}

\section{Study of Sulfidation Kinetics}

Sulfidation kinetics tests were conducted in a thermogravimetric analyzer (TGA) system on 2-3 $\mathrm{mg}$ of the 125-180 micron fraction of the sorbents. The feed gas flowrate was $564 \mathrm{ml} / \mathrm{min}$ in all tests.

The specific surface areas of the tested sorbents were also measured. The surface areas were calculated using BET $\mathrm{N}_{2}$-desorption data.

\section{Parametric studies of Sulfidation}

Fixed-bed multicycle desulfurization testing continued this quarter. Tests were conducted in the quartz reactor system shown in Figure 1.

Tests were conducted using 250-850 micron particles of the $\mathrm{CuO}-\mathrm{Cr}_{2} \mathrm{O}_{3}$ and $\mathrm{CuO}-\mathrm{CeO}_{2}$ sorbents at $750^{\circ}$. Pre-reduction of the sorbents was conducted with a feed gas containing 10 or 30 vol\% $\mathrm{H}_{2}$ and 10 vol\% $\mathrm{H}_{2} \mathrm{O}$ in $\mathrm{N}_{2}$ at a space velocity of $2000 \mathrm{hr}^{-1}$ (STP). Feed gases containing $5000 \mathrm{ppm} \mathrm{H}_{2} \mathrm{~S}$, 10 or 30 vol\% $\mathrm{H}_{2}$ and 10 vol\% $\mathrm{H}_{2} \mathrm{O}$ in $\mathrm{N}_{2}$ was used to sulfide the sorbents at the same space velocity. Regeneration of the sulfided sorbents were conducted using 3 vol $\%-\mathrm{O}_{2}$ in $\mathrm{N}_{2}$-gas. The regeneration temperature was $750^{\circ} \mathrm{C}$ for all except the second regeneration of the $\mathrm{CuO}-\mathrm{CeO}_{2}$ sorbent, which was conducted at $850^{\circ} \mathrm{C}$.

\section{RESULTS AND DISCUSSION}

\section{Measurement of Specific Surface Area}

The specific surface area of the $\mathrm{CuO}-\mathrm{Cr}_{2} \mathrm{O}_{3}$ and $\mathrm{CuO}-\mathrm{CeO}_{2}$ sorbents and the two copper-and additive-rich sorbents are shown in Table 1 . The results are typical of those obtained 
for these sorbents during the first year of this program.

Table 1. SPECIFIC SURFACE AREAS OF FRESH SORBENTS

\begin{tabular}{||c|c|c|c||}
\hline \multirow{2}{*}{ Sorbent } & \multicolumn{2}{|c|}{ Calcination Conditions } & \multirow{2}{*}{$\begin{array}{c}\text { Surface } \\
\text { Area, } \mathrm{m}^{2} / \mathrm{g}\end{array}$} \\
\cline { 2 - 3 } & Temp., ${ }^{\circ} \mathrm{C}$ & Time, hr & \\
\hline $3 \mathrm{CuO}-\mathrm{CeO}_{2}$ & 1000 & 1 & 4.34 \\
\hline $\mathrm{CuO}-\mathrm{CeO}_{2}$ & 925 & 1 & \\
\hline $\mathrm{CuO}-3 \mathrm{CeO}_{2}$ & 1000 & 1 & \\
\hline & & 1 & 2.18 \\
\hline $3 \mathrm{CuO}-\mathrm{Cr}_{2} \mathrm{O}_{3}$ & 1000 & 1 & \\
\hline $\mathrm{CuO}-\mathrm{Cr}_{2} \mathrm{O}_{3}$ & 925 & 1 & \\
\hline $\mathrm{CuO}-3 \mathrm{Cr}_{2} \mathrm{O}_{3}$ & 1000 & & \\
\hline
\end{tabular}

Study of Sulfidation Kinetics

Sulfidation-Regeneration Cycles With/Without PreReduction in the TGA

A summary of the reaction conditions used in the TGA sulfidation-regeneration tests is given in Table 2 .

\section{Pre-Reduction}

Figure 2 a shows the normalized weight changes of the $\mathrm{CuO}-\mathrm{CeO}_{2}$ sorbent during pre-reduction at $750^{\circ} \mathrm{C}$ using 30 vol\% $\mathrm{H}_{2}$ and 10 vol\% $\mathrm{H}_{2} \mathrm{O}$. In these figures $\mathrm{W}_{0}$ represents the original sample weight and $\mathrm{W}$ is the sample weight at reaction time $>0$. Similar results were obtained for the reduction in 10 vol\% $\mathrm{H}_{2}$. For all three cycles in both $\mathrm{H}_{2}$ gas mixtures, $W / W_{\circ}$ decreased rapidly and reached a constant value within about 0.5 minutes. Theoretically, if all the CuO in the sorbent is reduced to $\mathrm{Cu}$, the $\mathrm{W} / \mathrm{w}_{\circ}$ should be 0.937 . Reduction was found to be faster in $30 \% \mathrm{H}_{2}$.

The CuO- $\mathrm{Cr}_{2} \mathrm{O}_{3}$ sorbent in $10 \%$ and $30 \% \mathrm{H}_{2}$ demonstrated similar rapid reduction of the CuO except that the reduction rates for the 1st cycles are much faster than those of the 2 nd and 3 rd cycles. The difference may be due to the changes of physical and chemical characteristics of the sorbents after regeneration. 


\begin{tabular}{|c|c|c|c|c|c|c|c|c|}
\hline \multirow[b]{3}{*}{ Sorbent ${ }^{(a)}$} & \multicolumn{6}{|c|}{ Gas Composition, vol\% } & \multirow{2}{*}{\multicolumn{2}{|c|}{ No. of Cycles }} \\
\hline & \multicolumn{3}{|c|}{ Reduction } & \multicolumn{3}{|c|}{ Sulfidation } & & \\
\hline & $\mathrm{H}_{2}$ & $\mathrm{H}_{2} \mathrm{O}$ & $\mathrm{N}_{2}$ & $\mathrm{H}_{2}$ & $\mathrm{H}_{2} \mathrm{O}$ & $\mathrm{N}_{2}$ & Sulf. & Reg. \\
\hline$A, B, C, D, E, F$ & 10 & 10 & 80 & 10 & 10 & 80 & $3,51 / 2^{(b)}$ & $2,3^{(c)}, 51 / 2^{(b)}$ \\
\hline $\mathrm{A}, \mathrm{B}$ & 30 & 10 & 60 & 30 & 10 & 60 & 3 & 2 \\
\hline$A, B$ & 0 & 0 & 0 & 10 & 10 & 80 & 3 & 2 \\
\hline$A, B$ & 0 & 0 & 0 & 30 & 10 & 60 & 3 & 2 \\
\hline
\end{tabular}

(a) $\mathrm{A}=\mathrm{CuO}-\mathrm{Cr}_{2} \mathrm{O}_{3}$

$\mathrm{B}=\mathrm{CuO}-\mathrm{CeO}_{2}$

$\mathrm{C}=\mathrm{CuO}-3 \mathrm{Cr}_{2} \mathrm{O}_{3}$

$\mathrm{D}=\mathrm{CuO}-\mathrm{Cr}_{2} \mathrm{O}_{3}$

$E=\mathrm{CuO}-3 \mathrm{CeO}_{2}$

$\mathrm{F}=3 \mathrm{CuO}-\mathrm{CeO}_{2}$

${ }^{(b)} \mathrm{B}$

${ }^{(c)} \mathrm{C}, \mathrm{D}, \mathrm{E}$ and $\mathrm{F}$

Table 2. TGA TEST CONDITIONS 
Comparing the reduction of $\mathrm{CuO}-\mathrm{CeO}_{2}$ with that of $\mathrm{CuO}-\mathrm{Cr}_{2} \mathrm{O}_{3}$ under the same $\mathrm{H}_{2}$ concentration, it was found that the reducibility of $\mathrm{CuO}$ is higher in the $\mathrm{CuO}-\mathrm{CeO}_{2}$ mixed oxide.

\section{Sulfidation Following Pre-Reduction}

The $W / W_{0}$ increased and slightly exceeded 1 during sulfidation after pre-reduction, as shown in Figure $2 \mathrm{~b}$ for $\mathrm{CuO}-\mathrm{CeO}_{2}$. Similar results were obtained for $\mathrm{CuO}-\mathrm{Cr}_{2} \mathrm{O}_{3}$. The excess of $W / W_{0}$ over 1 might result from the participation of $\mathrm{CeO}^{2}$ or $\mathrm{Cr}_{2} \mathrm{O}_{3}$ in the reaction, or the formation of other $\mathrm{Cu}-\mathrm{S}$ products besides $\mathrm{Cu}_{2} \mathrm{~S}$. Preliminary calculations show that sulfidation under $30 \% \mathrm{H}_{2}$ may be slower for both sorbents.

\section{Sulfidation Without Pre-Reduction}

As shown in Figure $3 a$ for $\mathrm{CuO}-\mathrm{CeO}_{2}$, sulfidation without pre-reduction consists of two stages, reduction-dominating stage and sulfidation-dominating stage. For $\mathrm{CuO}-\mathrm{CeO}_{2}$ and $\mathrm{CuO}-$ $\mathrm{Cr}_{2} \mathrm{O}_{3}$ sorbents, $\mathrm{W} / \mathrm{W}$ 。 reached the minimum values within about $0.2-0.3$ and 0.4-0.5 minutes, respectively, indicating that reduction of $\mathrm{CuO}$ to $\mathrm{Cu}$ was dominant during this period, and then increased to over 1 within the next 1.5 and 1.2 minutes, respectively, corresponding to $\mathrm{Cu} / \mathrm{CuO}$ sulfidation to $\mathrm{Cu}_{2} \mathrm{~S}$. Referring to the weight loss in pre-reduction, it appears that sulfidation takes place before cuo was completely reduced. When the low $\mathrm{H}_{2}$ concentration was used, less CuO was reduced to $\mathrm{Cu}$ before suifidation became dominant, due to lower reduction rate.

Regeneration

The changes of $\mathrm{W} /$ Wo versus time are different for the $\mathrm{CuO}-\mathrm{CeO}_{2}$ (Figures $2 \mathrm{C}$ and $3 \mathrm{~b}$ ) and $\mathrm{CuO}-\mathrm{Cr}_{2} \mathrm{O}_{3}$ sorbents in the regeneration stage. For $\mathrm{CuO}-\mathrm{CeO}_{2}, \mathrm{~W} /$ Wo was constant or increased slightly, implying that $\mathrm{CuSO}_{4}$ or $\mathrm{Ce}_{2}\left(\mathrm{SO}_{4}\right)_{3}$ might have formed besides CuO. But for $\mathrm{CuO}-\mathrm{Cr}_{2} \mathrm{O}_{3} \mathrm{~W} /$ Wo decreased to 1 or below 1, suggesting that $\mathrm{Cu}$ sulfides were not all oxidized to $\mathrm{CuO}$; other $\mathrm{Cu}$ oxides such as $\mathrm{Cu}_{2} \mathrm{O}$ might also have been produced.

\section{Evaluation of Various Sorbent Compositions}

Reduction-sulfidation-regeneration cycles for sorbents with $\mathrm{CuO} / \mathrm{CeCeO}_{2}=1: 3,3: 1$ and $\mathrm{CuO} / \mathrm{Cr}_{2} \mathrm{O}_{3}=1: 3,3: 1$ were also carried out during this quarter to examine the effect of sorbent composition on the reduction-sulfidation-regeneration rates. The results of these tests are summarized below. 
Cu-Ce-O Sorbents

It was found that the reduction rate increased with the increase of $\mathrm{CuO} / \mathrm{CeO}_{2}$ mole ratio. The cuo contained in sorbents $\mathrm{CuO}_{3}-3 \mathrm{CeO}_{2}$ (and $\mathrm{CuO}-\mathrm{CeO}_{2}$ ) was $100 \%$ reduced in these reduction experiments. However, only $88 \%$ of the available cuo was reduced in the sorbents $3 \mathrm{CuO}-\mathrm{CeO}_{2}$.

During sulfidation, W/Wo exceeds 1 for all three $\mathrm{Cu}-\mathrm{Ce}-\mathrm{O}$ sorbents. The $\mathrm{CeO}_{2}$-based materials have similar rates (week function of composition). A trend exists for the $\mathrm{Cr}_{2} \mathrm{O}_{3}$-based sorbents. The sulfidation rate drops with increased $\mathrm{Cr}_{2} \mathrm{O}_{3}$ content.

During regeneration, $w /$ Wo increased slightly for CuO$3 \mathrm{CeO}_{2}$ in both cycles exhibiting the same behavior as that of $\mathrm{CuO}-\mathrm{CeO}_{2}$. But for $3 \mathrm{CuO}-\mathrm{CeO}_{2}$, an interesting phenomenon was observed. When air was introduced into the TGA reactor, the weight of the sorbent decreased first and then increased to a slightly higher level than the initial regeneration weight for all three cycles. The decrease of the weight suggests that $\mathrm{Cu}$ sulfides may be oxidized to $\mathrm{Cu}_{2} \mathrm{O}$ first and then to CuO.

\section{Cu-Cr-O Sorbents}

The reduction of $\mathrm{CuO}-3 \mathrm{Cr}_{2} \mathrm{O}_{3}$ is similar to that of CuO$3 \mathrm{CeO}_{2}$ for all three cycles. CuO was reduced to $\mathrm{Cu}$ within 0.3 minutes. The conversion is 0.9 for the first cycle. For the $3 \mathrm{CuO}-\mathrm{Cr}_{2} \mathrm{O}_{3}$ sorbent there is a substantial difference between reduction in the first and the later two cycles. The conversion of $\mathrm{CuO}$ to $\mathrm{Cu}$ is only 0.51 for the first cycle, even lower than that for $\mathrm{CuO} / \mathrm{Cr}_{2} \mathrm{O}_{3}-1: 1$, while the weight losses in the second and third cycles were larger because of the weight increase during the first sulfidation stage.

During sulfidation, the $\mathrm{W} / \mathrm{Wo}$ for $\mathrm{CuO}-3 \mathrm{Cr}_{2} \mathrm{O}_{3}$ sorbent returned to 1 in the first cycle and slightly less than 1 in the second and third cycles. For $3 \mathrm{CuO}-\mathrm{Cr}_{2} \mathrm{O}_{3},(\mathrm{~W} / \mathrm{Wo})$ increased greatly, reaching about $1.07,1.083$, and 1.087 in the first, second, and third cycles, respectively.

The $\mathrm{W} /$ Wo kept constant during regeneration of the CuO$3 \mathrm{Cr}_{2} \mathrm{O}_{3}$ contrary to the decrease for $\mathrm{CuO}-\mathrm{Cr}_{2} \mathrm{O}_{3}$ sorbent. As for $3 \mathrm{CuO}-\mathrm{Cr}_{2} \mathrm{O}_{3}$, it exhibited he same behavior as that for $3 \mathrm{CuO}-$ $\mathrm{CeO}_{2}$; decreased first and then increased, except that the final weight was less than the weight before regeneration. 
Reaction Rate Calculations

Initial reaction rates for both reduction and sulfidation were calculated according to the equation:

$$
R_{c}=(d W / d t)_{t=0} /\left(M * W_{0} \star S\right)
$$

where: $R_{0}=$ initial rate, $\operatorname{mmol} \cdot \mathrm{sec}^{-1} \cdot \mathrm{cm}^{-2} ;(\mathrm{dW} / \mathrm{dt})_{t=0}=$ slope of the weight vs. time profile at $t=0, \mathrm{mg} / \mathrm{s} ; \mathrm{M}=$ molecular weight, $\mathrm{mg} / \mathrm{mmol}$, for reduction it is 79.55 , for sulfidation it is $63.55 ; W_{0}=$ initial sample weight, $\mathrm{mg} ; \mathrm{S}=$ specific surface area of sorbent, $\mathrm{cm}^{2} / \mathrm{mg}$. The results of these calculations will be presented next quarter.

\section{Measurement of $\mathrm{SO}_{2} / \mathrm{H}_{2} \underline{\mathrm{S}}$}

The concentration of $\mathrm{SO}_{2}$ and $\mathrm{H}_{2} \mathrm{~S}$ in the TGA off-gas during sulfidation without pre-reduction was measured for both Cuo$\mathrm{CeO}_{2}$ and $\mathrm{CuO}-\mathrm{Cr}_{2} \mathrm{O}_{3}$ sorbents by GC/FPD. Two gas mixtures, with and without water, were used.

It was confirmed that $\mathrm{SO}_{2}$ was formed during direct sulfidation of both the sorbents, with or without water in the feed gases. No suppression effect of $\mathrm{H}_{2} \mathrm{O}$ on $\mathrm{SO}_{2}$ formation was found for $\mathrm{CuO}-\mathrm{CeO}_{2}$, while this was verified for $\mathrm{CuO}-\mathrm{Cr}_{2} \mathrm{O}_{3}$. Because the amount of sample used was very small ( $<5 \mathrm{mg}$ ) and the gas flow rate was high, the release of $\mathrm{SO}_{2}$ was very fast and some may have gone out undetected.

\section{Parametric studies of sulfidation}

The results of the fixed-bed reactor tests are shown in Figures 4-7 in terms of the concentration of $\mathrm{H}_{2} \mathrm{~S}$ in the product gas as a function of the normalized time $t / t^{*}$. Here $t^{*}$ is the theoretical time corresponding to complete sulfidation of the active sorbent components, calculated by assuming copper oxide as the only active phase sulfided by $\mathrm{H}_{2} \mathrm{~S}$ to $\mathrm{Cu}_{2} \mathrm{~S}$.

Figure 4 shows the $\mathrm{H}_{2} \mathrm{~S}$ breakthrough profiles over three cycles for the $\mathrm{CuCr}_{2} \mathrm{O}_{4}$ sorbent in the fixed-bed reactor at $750^{\circ} \mathrm{C}$, using a feed gas containing 5000 ppmv $\mathrm{H}_{2} \mathrm{~S}, 10$ vol\% $\mathrm{H}_{2}$ and 10 vol\% $\mathrm{H}_{2} \mathrm{O}$ in $\mathrm{N}_{2}$ after pre-reduction with the 10 vol\% $\mathrm{H}_{2}-$ 10 vol\% $\mathrm{H}_{2} \mathrm{O}$ containing gas mixture. The $\mathrm{H}_{2} \mathrm{~S}$ concentration of the feed gas was reduced from 5000 ppmv to less than 1 ppmv to 10 ppmv while utilizing from $70 \%$ to nearly $90 \%$ of the copper, which is similar to the results obtained without pre-reduction (presented in the first quarterly report). Regeneration of the sulfided $\mathrm{Cr}_{2} \mathrm{O}_{4}$ sorbent at $750^{\circ} \mathrm{C}$ and a 3 vol\% $\mathrm{O}_{2}-\mathrm{N}_{2}$ gas feed mixture was rapid and complete. 
Figure 5 shows the $\mathrm{H}_{2} \mathrm{~S}$ breakthrough profiles over three cycles for the $\mathrm{CuO}-\mathrm{Cr}_{2} \mathrm{O}_{3}$ sorbent in the fixed-bed reactor at $750^{\circ} \mathrm{C}$, using a feed gas containing 5000 ppmv $\mathrm{H}_{2} \mathrm{~S}, 30$ vol\% $\mathrm{H}_{2}$ and 10 vol\% $\mathrm{H}_{2} \mathrm{O}$ in $\mathrm{N}_{2}$. $\mathrm{H}_{2} \mathrm{~S}$ levels in the product gas were less than 10 ppmv for conversions up to 0.3 to 0.5 , followed by increases remaining at 100-200 ppmv up to a second breakthrough at copper conversions of 0.9 to over 1.1 . Figure 6 shows the $\mathrm{H}_{2} \mathrm{~S}$ breakthrough profiles using the same gas feed mixture but after pre-reduction with the 30 vol\% $\mathrm{H}_{2}-10$ vol\% $\mathrm{H}_{2} \mathrm{O}$ containing gas mixture. The breakthrough curves are similar to those obtained without pre-reduction.

Figure 7 shows the $\mathrm{H}_{2} \mathrm{~S}$ breakthrough profiles over three cycles for the $\mathrm{CuO}-\mathrm{CeO}_{2}$ sorbent in the fixed-bed reactor at $750^{\circ} \mathrm{C}$, using a feed gas containing 5000 ppmv $\mathrm{H}_{2} \mathrm{~S}, 30$ vol\% $\mathrm{H}_{2}$ and 10 vol\% $\mathrm{H}_{2} \mathrm{O}$ in $\mathrm{N}_{2}$. In the first cycle, $\mathrm{H}_{2} \mathrm{~S}$ levels in the product gas were less than 1 to 10 ppmv for a conversion up to 0.8 , followed by an increase to 100-200 ppmv up to breakthrough at a $t / t^{*}$ of 2.3 . In the next two cycles, however, the $\mathrm{H}_{2} \mathrm{~S}$ pre-breakthrough levels rose rapidly to 20-40 ppmv and increased gradually until the second $\mathrm{H}_{2} \mathrm{~S}$ breakthrough was reached. Regeneration of the sulfided $\mathrm{CuO}-\mathrm{CeO}_{2}$ sorbent was conducted at $750^{\circ} \mathrm{C}$ and a 3 vol\% $\mathrm{O}_{2}-\mathrm{N}_{2}$ gas feed mixture for the first regeneration. Regeneration at $850^{\circ} \mathrm{C}$ in the second cycle did not improve the sulfidation performance of the sorbent in the succeeding cycle. It is possible that the sulfates formed in the first cycle may not have decomposed at $850^{\circ} \mathrm{C}$.

The effects of pre-reducing the $\mathrm{CuO}-\mathrm{CeO}_{2}$ on its sulfidation performance will be determined in fixed-bed tests to be conducted next quarter. XRD and surface area analyses will be used to characterize the sulfided and regenerated sorbents.

\section{CONCLUSIONS AND RECOMMENDATIONS}

The following conclusions can be made from the results obtained this quarter:

- Reduction is a much faster compared to sulfidation

- Reduction under $30 \% \mathrm{H}_{2}$ is faster than under $10 \% \mathrm{H}_{2}$

- The rate of sulfidation does not appear to be significantly affected by pre-reduction

- Sulfidation is slower under $30 \% \mathrm{H}_{2}$ than $10 \% \mathrm{H}_{2}$

- The reducibility of the sorbent is lowered in succeeding 
cycles

- Pre-reducing the $\mathrm{CuO}-\mathrm{Cr}_{2} \mathrm{O}_{4}$ with $\mathrm{H}_{2}$ does not effect the reactivity of the sorbent towards $\mathrm{H}_{2} \mathrm{~S}$ after three cycles at either high or low $\mathrm{H}_{2}$ concentrations

- When $30 \% \mathrm{H}_{2}$ was used during sulfidation of both $\mathrm{CuO}-\mathrm{CeO}_{2}$ and $\mathrm{CuO}-\mathrm{Cr}_{2} \mathrm{O}_{4}$, the first $\mathrm{H}_{2} \mathrm{~S}$ breakthrough occurs earlier than when $10 \% \mathrm{H}_{2}$ was used. 
REFERENCES CITED

1. MERC - Hot Gas Cleanup Force, Final Report, MERC/SP-78/2, Morgantown, WV, 1978.

2. Grindley, T. and G. Steinfeld, "Development and Testing of Regenerable Hot Coal Gas Desulfurization Sorbents", Final Report No. DOE/MC/16545-1125, 1981.

3. Jalan, V. and D. Wu, "High Temperature Desulfurization of Fuel Gases for Molten Carbonate Fuel Cell Power Plants", Paper presented at the National Fuel Cell Seminar, San Diego, CA, July 14-16, 1980.

4. Grindley, T. and G. Steinfeld, "Zinc Ferrite as Hydrogen Sulfide Absorbent", 3rd Ann. Contr. Mtg. on Contaminant Control in Coal-Derived Gas Streams, Rep. No. DOE/METC/84-6, 1983.

5. Anderson, G.L. et al., "Development of Hot Gas Cleanup system for Integrated Coal Gasification/Molten Carbonate Fuel Cell Plants", Final Report, No. DOE/MC/19403-1816, 1985.

6. Jalan, V. (Giner, Inc.), Final Report, DOE/MC/160211486,1983 .

7. Flytzani-Stephanopoulos, M., S.S. Tamhankar, P.K. Sharma and G.R. Gavalas, "Novel Sorbents for HighTemperature Regenerative $\mathrm{H}_{2} \mathrm{~S}$ Removal", Jet Propulsion Laboratory Final Report No. DOE/MC/20417-1898, October 1985.

8. Tamhankar, S.S., M. Bagajewicz, G.R. Gavalas, P.K. Sharma and

M. Flytzani-Stephanopoulos, Ind. Eng. Chem. Proc. Des. Dev. 25, 429437 (1986).

9. Flytzani-Stephanopoulos, M. et al., "High-Temperature Regenerative Removal of $\mathrm{H}_{2} \mathrm{~S}$ by Porous Mixed Oxide Sorbents", ACS Div. Fuel Chem. Preprints 30, 16-25 (1985).

10. Smith, K.J., G.B. Haldipur and J.L. Lucas, "KRW Process Development Coal Gasification/Hot Gas Cleanup", Proceedings, 7th Ann. Gasification and Gas Stream Cleanup Systems Contr. Rev. MLg. DOE/METC-87/6079, Vol. 2, p.668, June 1987.

11. Abbasian, J., Hill, A. H., and Wangerow, J. R., "Development of Novel Copper-Based Sorbents for Hot-Gas 
Cleanup," Final Technical Report, September 1, 1990-August 31, 1992, prepared by Institute of Gas Technology for Center for Research on sulfur in Coal.

12. Marcilly, C., Courty, P., and Delmon, B., "Preparation of Highly Dispersed Mixed Oxides and Oxide Solid Solutions by Pyrolysis of Amorphous Organic Precursors," J. Am. Ceram. Soc. 53(1), 56-57:1970).

This work was prepared with the support, in part, by grants made possible by the Illinois Department of Energy and Natural Resources through its Coal Development Board and Illinois Clean Coal Institute, and by the U.S. Department of Energy. However, any opinions, findings, conclusions, or recommendations expressed herein are those of the author(s) and do not necessarily reflect the views of IDENR, ICCI, and the DOE. 


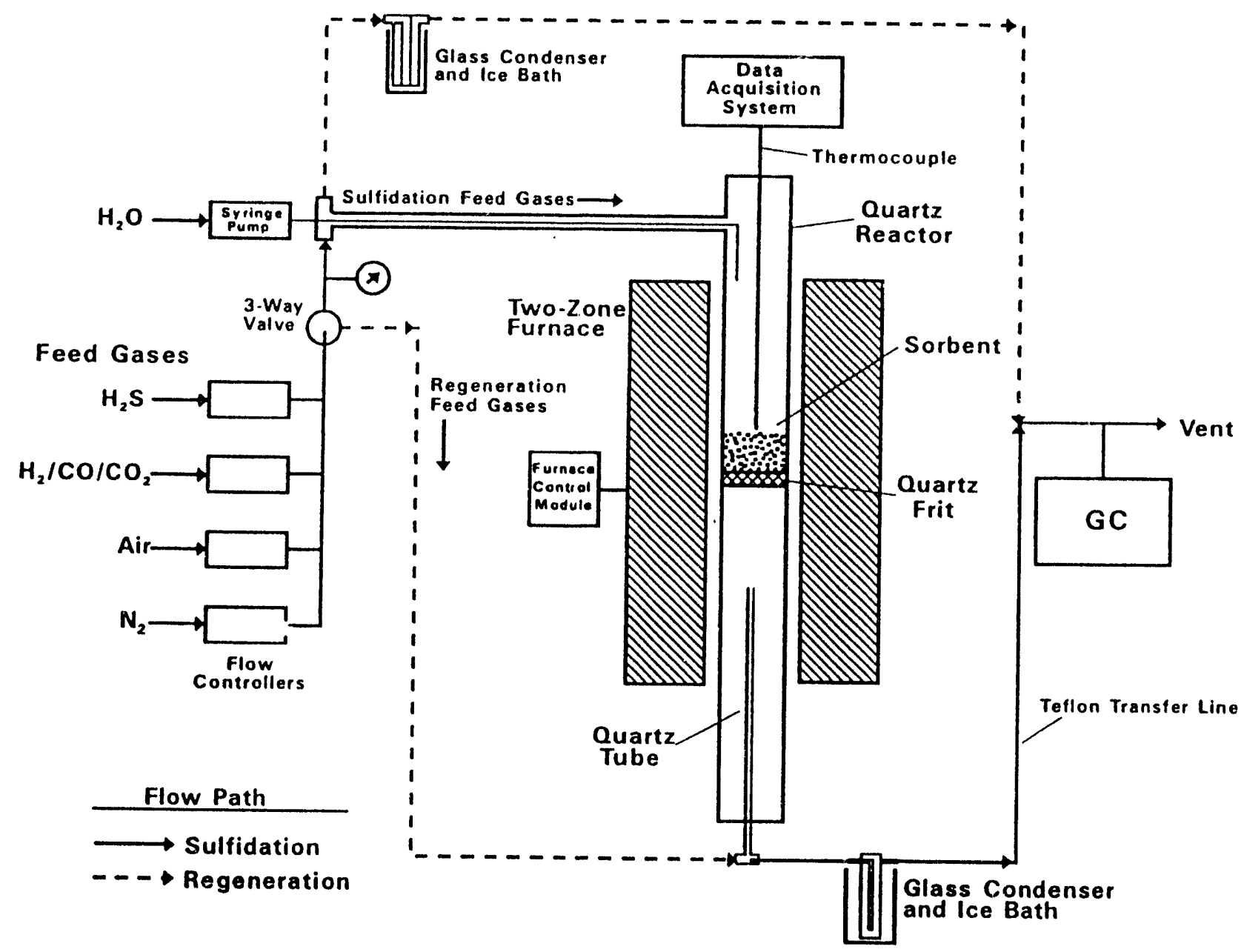

FIGURE 1. EXPERIMENTAL SETUP FOR THE 2.5-CM ID QUARTZ REACTOR 

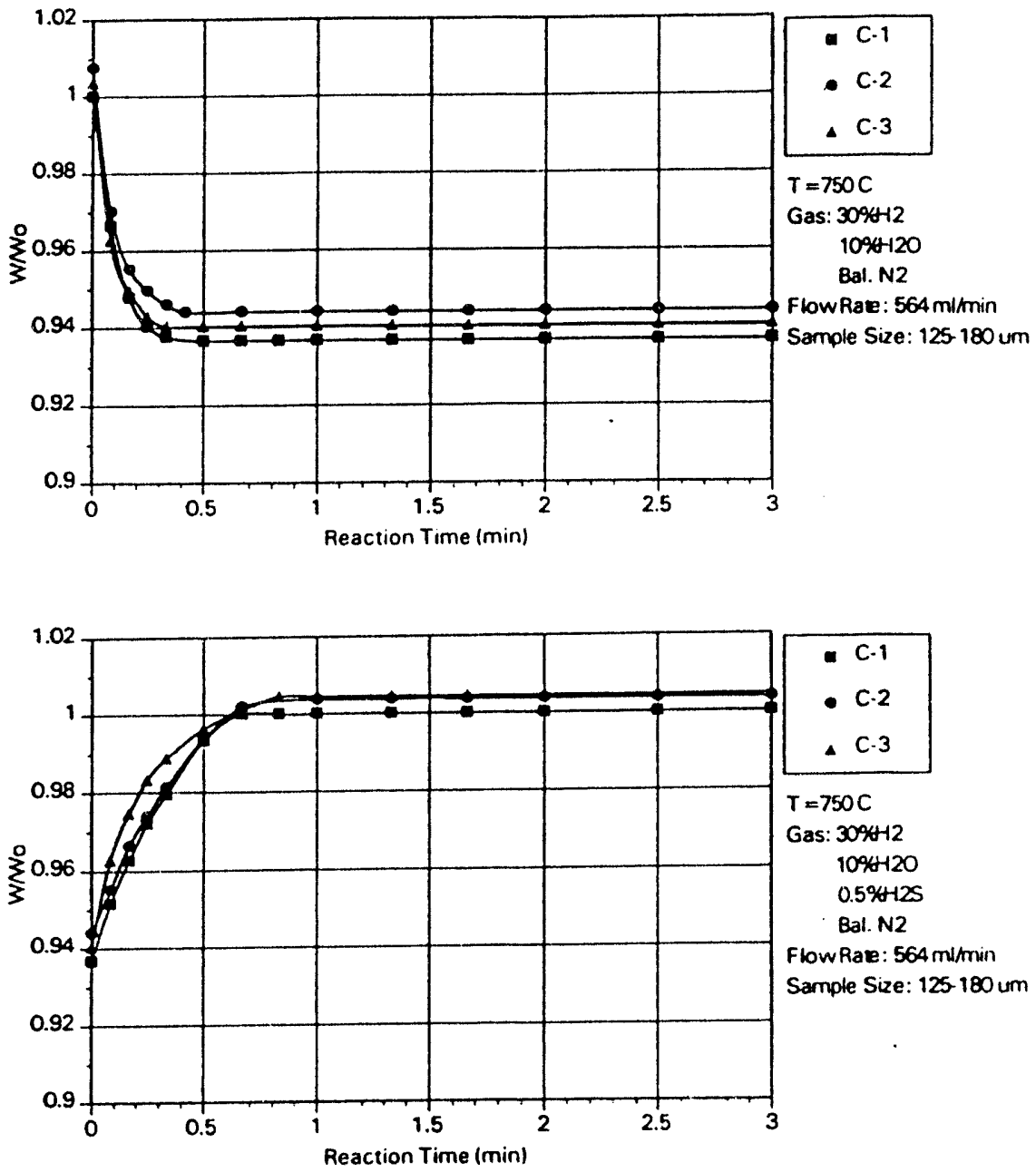

$T=750 \mathrm{C}$

Gas: $30 \%+2$

$10 \%+20$

$0.5 \%+25$

Bal. N2

Flow Rae: $564 \mathrm{~m} / \mathrm{min}$

Sample Size: 125-180 um

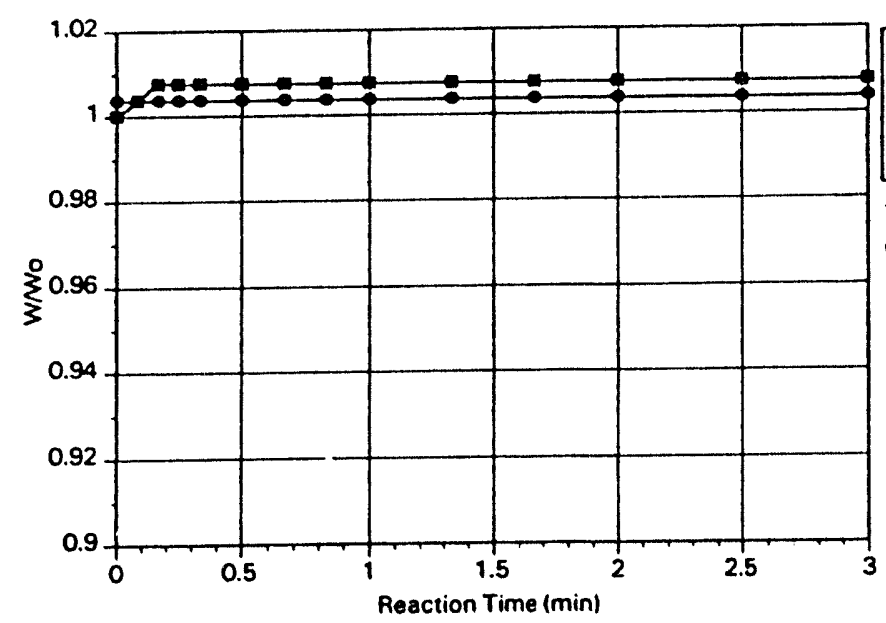

- C.1

- C-2

$T=750 \mathrm{C}$

Gas: $6 \% 02$

Bal. N2

Flow Rae: $564 \mathrm{ml} / \mathrm{min}$

Sample Size: $125-180$ um

FIGURE 2. NORMALIZED WEIGHT CHANGES OF $\mathrm{CUO}-\mathrm{CeO}_{2}$ IN TGA WITH PRE-REDUCTION AT $30 \% \mathrm{H}_{2}$

(a) Reduction, (b) Sulfidation at $30 \% \mathrm{H}_{2}$, (c) Regeneration 

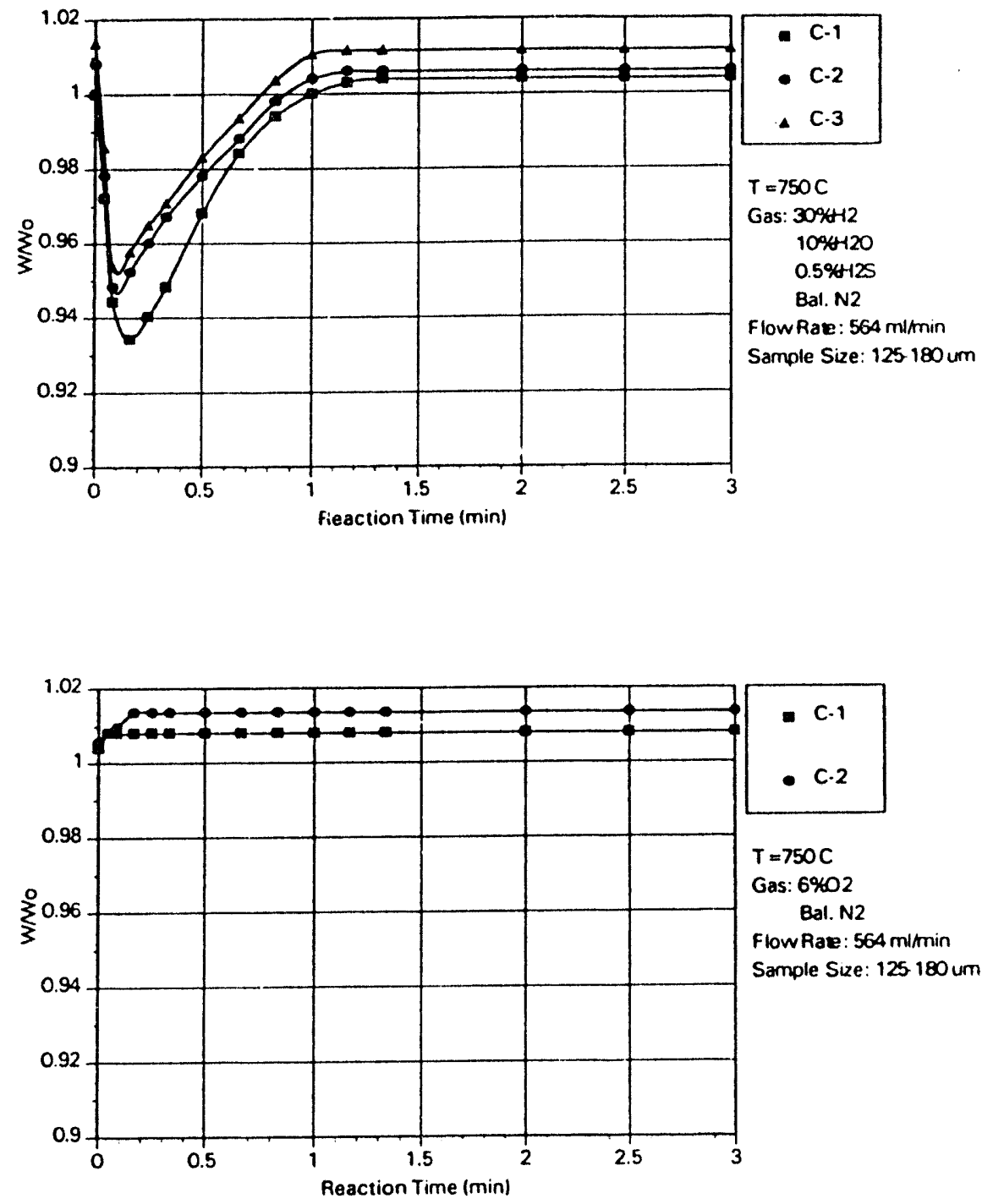

FIGURE 3. NORMALIZED WEIGHT CHANGES OF $\mathrm{CuO}-\mathrm{CeO}_{2}$ IN TGA WITHOUT PRE-REDUCTION

(b) Sulfidation at $30 \% \mathrm{H}_{2}$, (c) Regeneration 


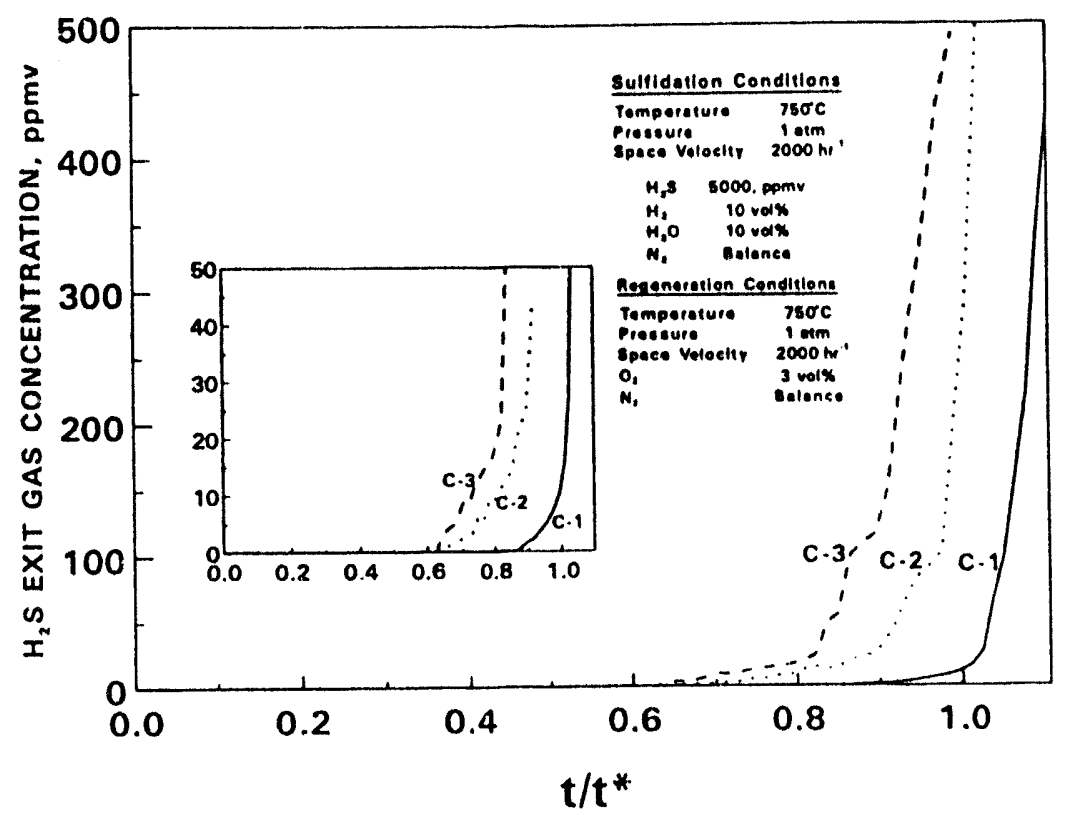

FIGURE 4. $\mathrm{H}_{2} \mathrm{~S}$ BREAKTHROUGH PROFILES OF CUO- $\mathrm{Cr}_{2} \mathrm{O}_{3}$ IN FIXED-BED REACTOR AFTER PRE-REDUCTION AT 10\% $\mathrm{H}_{2}$

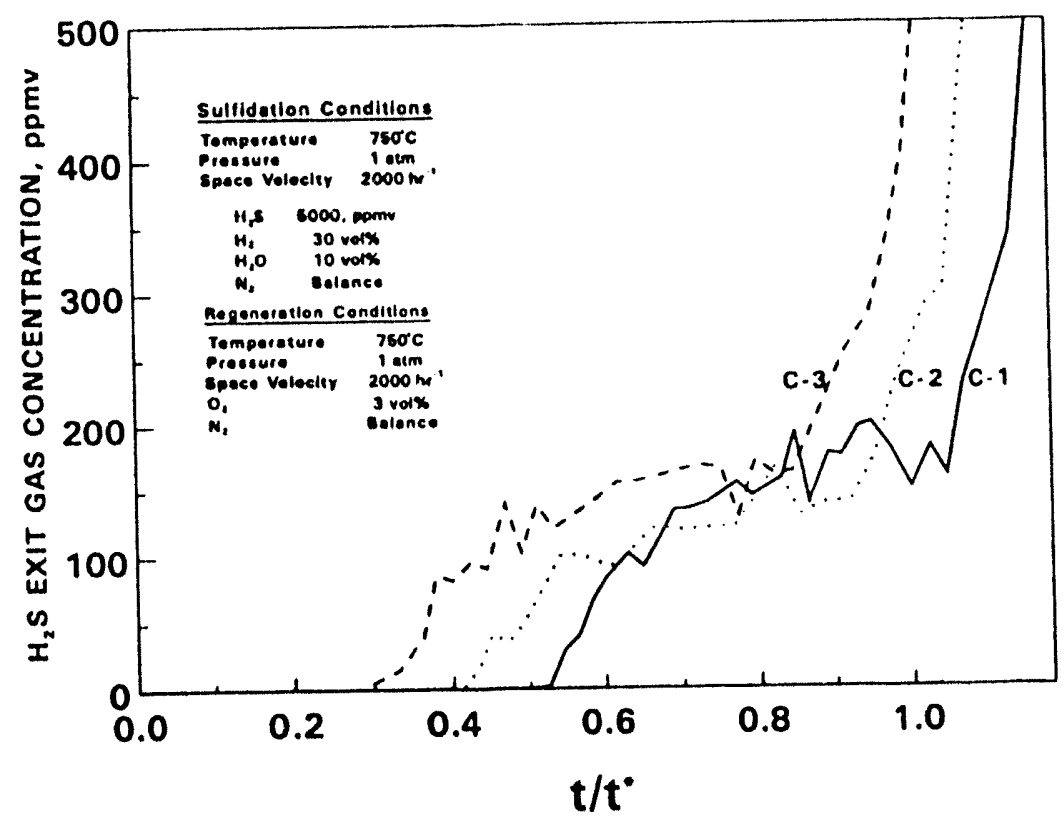

FIGURE 5. $\mathrm{H}_{2} \mathrm{~S}$ BREAKTHROUGH PROFILES OF CUO- $\mathrm{Cr}_{2} \mathrm{O}_{3}$ IN FIXED-BED REACTOR AT 30\% $\mathrm{H}_{2}$ WITHOUT PRE-REDUCTION 


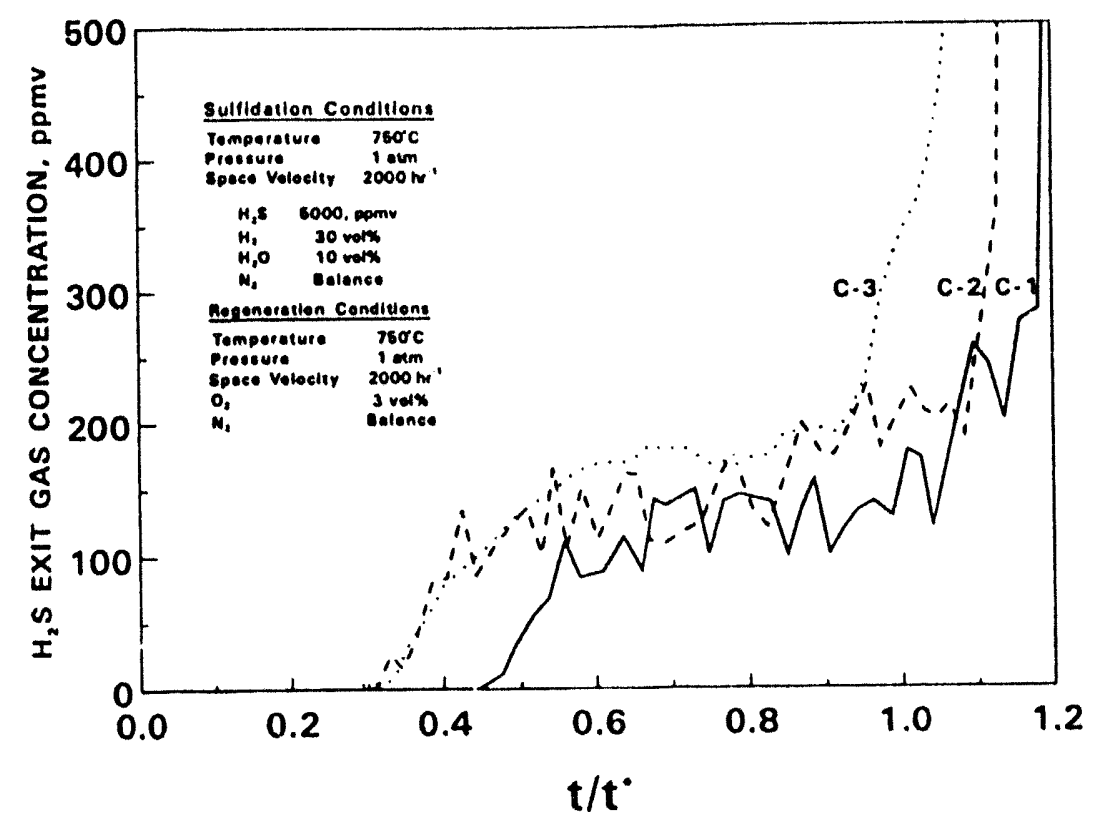

FIGURE 6. $\mathrm{H}_{2} \mathrm{~S}$ BREAKTHROUGH PROFILES OF CUO- $\mathrm{Cr}_{2} \mathrm{O}_{3}$ IN FIXED-BED REACTOR AFTER PRE-REDUCTION AT $30 \% \mathrm{H}_{2}$

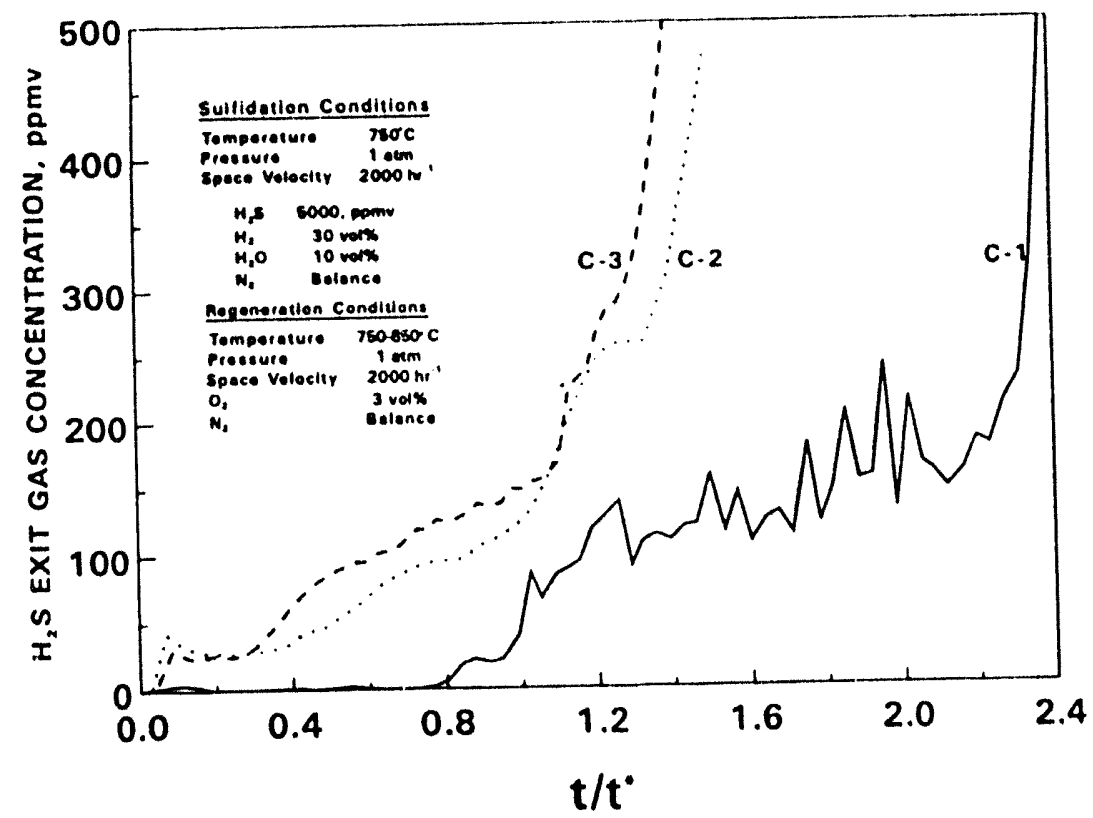

FIGURE 7. $\mathrm{H}_{2} \mathrm{~S}$ BREAKTHROUGH PROFILES OF $\mathrm{CUO}-\mathrm{CeO}_{2}$ IN FIXED-BED REACTOR AT 30\% $\mathrm{H}_{2}$ WITHOUT PRE-REDUCTION 

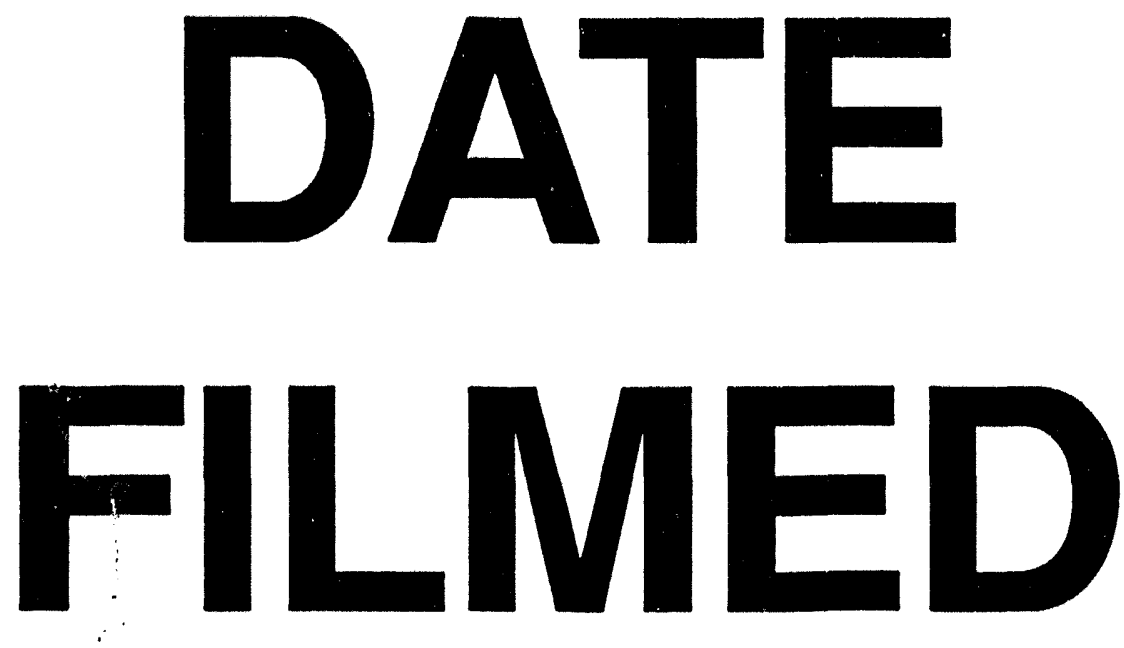

$6 / 22 / 94$
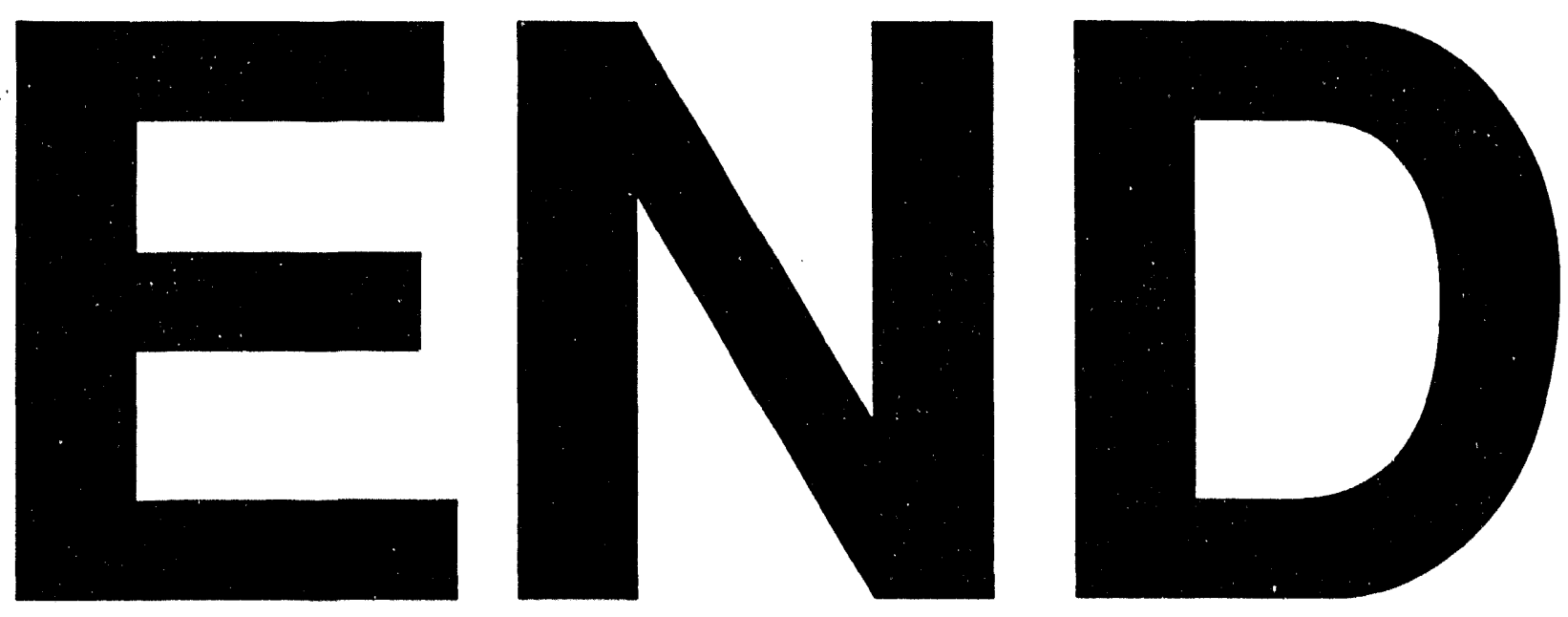


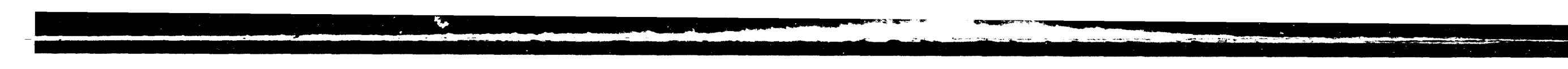

